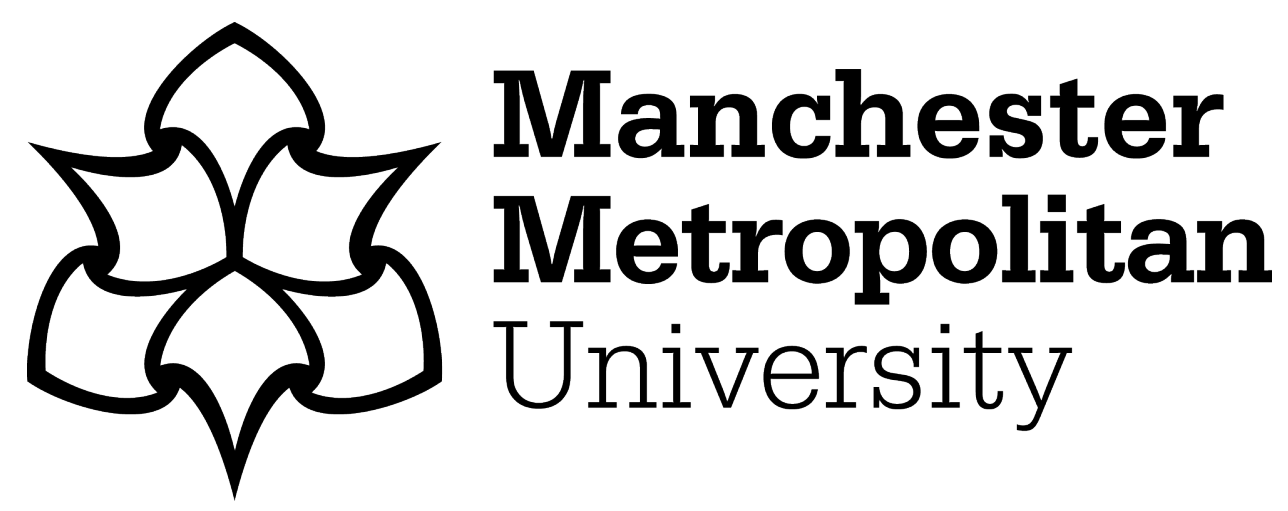

Cutter-Mackenzie, A and Rousell, DS (2018) Education for What? Shaping the field of climate change education with children and young people as coresearchers. Children's Geographies, 17 (1). pp. 90-104. ISSN 1473-3277

Downloaded from: https://e-space.mmu.ac.uk/620729/

Version: Accepted Version

Publisher: Taylor \& Francis (Routledge)

DOI: https://doi.org/10.1080/14733285.2018.1467556

Please cite the published version 


\title{
Education for What?
}

Shaping the field of climate change education with children and young people as coresearchers

\begin{abstract}
Children are often positioned as the next generation of leaders in whom the public imagines or expects to overcome the legacies of environmental inaction. Increasingly analyses of progress in environmental education independently identify the need for researchers and teachers to 'listen to children's voices'. In this paper we argue that climate change education presents a significant platform not only for youth voices, but also for a genuine activation of children's political agency in schools, universities, and the public domain. In so doing, we draw upon the government funded project Climate Change and Me, which has involved working with 135 children and young people from across Northern NSW, Australia as co-researchers investigating young people's voices in climate change. We conclude that climate change education can open up an entirely new field of educational experience and inquiry when it is inclusive of and led by young people.
\end{abstract}

Keywords: climate change education; child-framed research; children's agency and voice.

\section{Introduction}

Over the last decade, the veracity of anthropogenic climate change and its associated impacts on the earth's systems has been established by distinguished scientists worldwide (Garnaut, 2011; IUPN, 2014). In each consecutive report released by the Intergovernmental Panel on Climate Change, the certainty and extent of climate change has been both confirmed and extended (IPCC, 2014; 2012; 2007). More recently, cultural issues associated with climate change (e.g. climate change refugees) have also become saturated within the public domain through diverse forms of informational, digital and social media, including television, film and the internet (Stokols, et al, 2009; Lowe et al, 2006). Numerous social justice issues have also been brought to the fore, as climate change is likely to impact most severely on Indigenous people in majority nations ${ }^{1}$ with relatively low ecological footprints (Crate \& Nuttall, 2009). This also applies to the issue of generational injustice, as children and young people are

\footnotetext{
${ }^{1}$ The term 'majority nations' is used to denote non-Western countries which make up the two-thirds of the Earth's human population. We refer to Western countries as minority nations.
} 
currently inheriting social and ecological problems which they have had very little part in creating. A recent Australian study of 10-14 year olds, for example, found that $50 \%$ of children were deeply concerned about climate change, while $25 \%$ of children were concerned that the world would end in their lifetimes (Tucci, Mitchell \& Goddard, 2007). It is thus widely acknowledged that innovative and effective forms of climate change education are needed for children and young people worldwide, who will be forced to grapple with the uncertainties of climate change brought forth by previous generations (Kagawa \& Selby, 2009). Climate change education, however, remains a relatively nascent and under-theorised area of inquiry as considered independently from established fields such as environmental education, science education and education for sustainable development (or education for sustainability) (Blum et al, 2013; Laessoe et al, 2009).

In this paper we argue that climate change education presents a significant platform not only for youth voices, but also for a genuine activation of children and young people's political agency in schools, universities, and the public domain. In responding to calls in environmental education, childhood studies and related fields to foreground children's voices on major social and environmental issues, we aim to extend the discourse to consider children's political agency, creativity and theoretical acumen as legitimate researchers into climate change education. In so doing, we draw upon the government funded project Climate Change and Me $(\mathrm{CC}+\mathrm{Me})$, which has involved working with 135 children and young people from across Northern NSW, Australia as co-researchers investigating the awareness, attitudes and actions towards climate change in their own communities. The artworks, essays, videos, photographs, poems and fictional works created through this research were assembled into a public touring exhibition in 2015 , and also provided the resources for a transdisciplinary climate change curriculum implemented in regional primary and secondary schools in New South Wales, Australia.

In the sections below, we look firstly at the emerging field of climate change education research from an international perspective, focusing on the disciplinary typology and distribution of the field based on a systematic literature review. This is followed by providing a brief background on the use of participatory and child-framed methodologies for educational research. We offer a brief account of the project design for the Climate Change and Me project, including the theoretical and methodological approaches we developed and employed over the course of the project. This is followed by a section which illustrates some 
of the data produced by the young co-researchers, as presented through three vignettes of collaborative works created for the Past Now Future exhibition. Following this account of the Climate Change and Me project, we further consider the implications for such participatory research in positioning climate change education as an emerging field in relation to environmental education and education for sustainability. We conclude that climate change education does not simply slip into one of these disciplines or sub-disciplines, but rather presents an emerging field of practice and research. More specifically, our findings suggest that climate change education can open up an entirely new field of educational experience and inquiry when it is inclusive of children and young people's voices, political agency and creativity.

\section{Climate Change Education: disciplinary typology and approach}

This section aims to contextualise the field of climate change education based on findings from our systematic review of literature published in the field between 1993 and 2014. This review found that existing climate change education research has tended to focus on children and young people's scientific knowledge of climate change, often describing it as limited, erroneous and highly influenced by mass media (see, for example, Lombardi, 2010). A number of recent studies, however, suggest that scientific knowledge-based approaches have been largely ineffectual in altering the attitudes and behavior of children and young people towards climate change (Dijkstra \& Goedhart, 2012; Brownlee, Powell \& Jeffrey, 2013). Research has also indicated that cognitive increases in knowledge about climate change has shown little to no correlation with pro-environmental attitudes or behaviour in the wider population (Dijkstra \& Goedhart, 2012). Selby and Kagawa (2010) even observe a trend towards climate change skepticism and denial in mainstream science education programs. These authors specifically target science educators as complicit in downplaying the ethical implications of climate change injustice, and framing climate change 'as an issue calling for a scientific or technical fix rather than as a pathology of an ethically numb, inequitable and denatured human condition' (p. 42). 


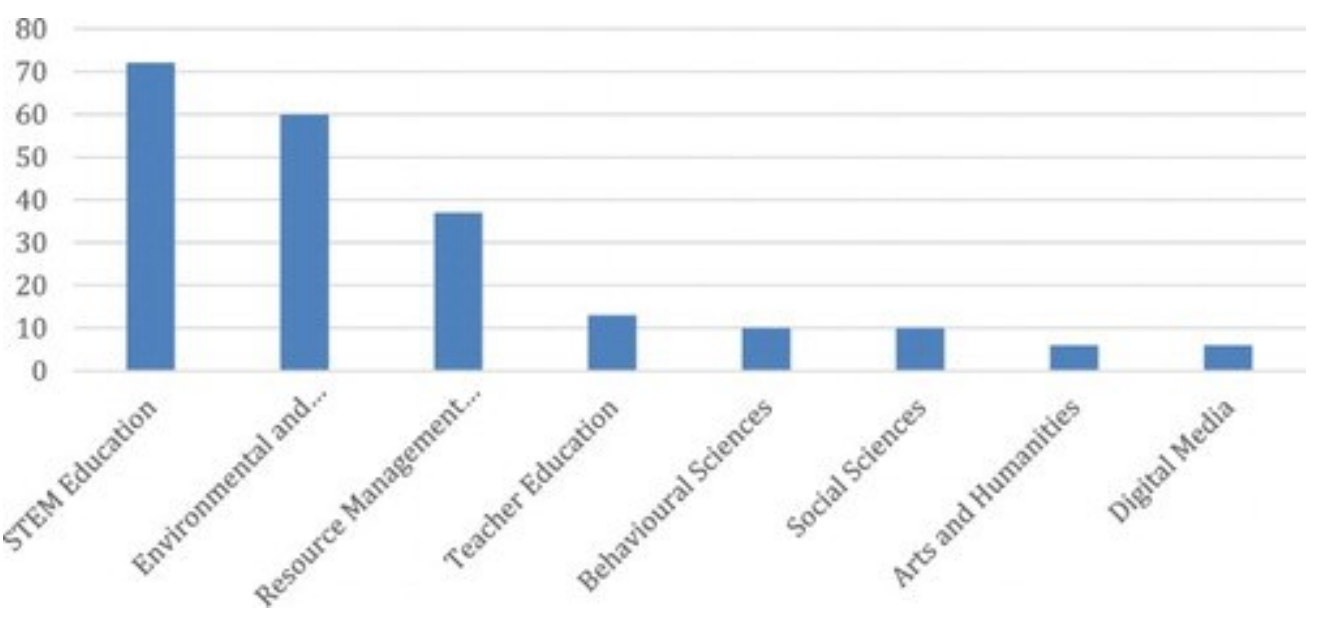

Figure 1: Disciplines associated with climate change education research

Figure 1 above shows the domination of the field of climate change education by fields of education associated with the physical sciences, technology, engineering and mathematics within the category of STEM. A large number of studies in the STEM category focused on the misconceptions and 'alternative conceptions' about climate change held by students, teachers and even scientific textbooks (Hallar, McCubbin \& Wright, 2011; Shepardson et al 2009; 2012; Choi et al, 2010; Fortner, 2001). A shift can also be located in the science education literature towards acknowledging the ethical and political implications of the issue (Kagawa \& Selby, 2012). Wise (2010, p. 297), for example, argues for an interdisciplinary instructional approach to climate change education, which would see the topic distributed across the curricula of the physical sciences, social sciences and the humanities. Sharma (2010) further argues that science education is, in itself, a powerful societal factor which can affect climate change attitudes and behavior at the cultural level. Climate change then has the potential to both transform and elevate the status of science education more broadly, as a discipline that has both ethical and political implications (Hill, 2010).

A large number of publications were also identified within the disciplinary subcategory of environmental education. These included publications that made direct reference to environmental education, or any of the associated fields of education for sustainability (EFS), education for sustainable development (ESD), or sustainability education. These publications tended to take a different perspective from the STEM education literature, due to the conceptual and methodological diversity that characterises research in environmental education (Hart \& Nolan, 1999). We did however find considerable tension around the naming and framing of climate change education as a standalone field alongside EFS, ESD and environmental education more broadly. Selby and Kagawa (2010), for example, advocate for 
climate change education as a much-needed antidote to the managerial and instrumental agendas that have recently overtaken the field of ESD. Anderson (2012), on the other hand, contends that climate change education should be comprehensively grounded within an ESD approach. Such an approach would involve the direct participation of children and young people as agents of change within their communities, and also establish strong partnerships between education policy-makers and climate scientists to inform climate change curricula with scientific expertise (p. 194). Laessoe et al (2009 p. 15) offer a third possible approach, in which climate change education is treated as an independent field of practice and inquiry which is related, and yet distinct, from ESD and other subsets of environmental education, while also operating outside the confines of general science education.

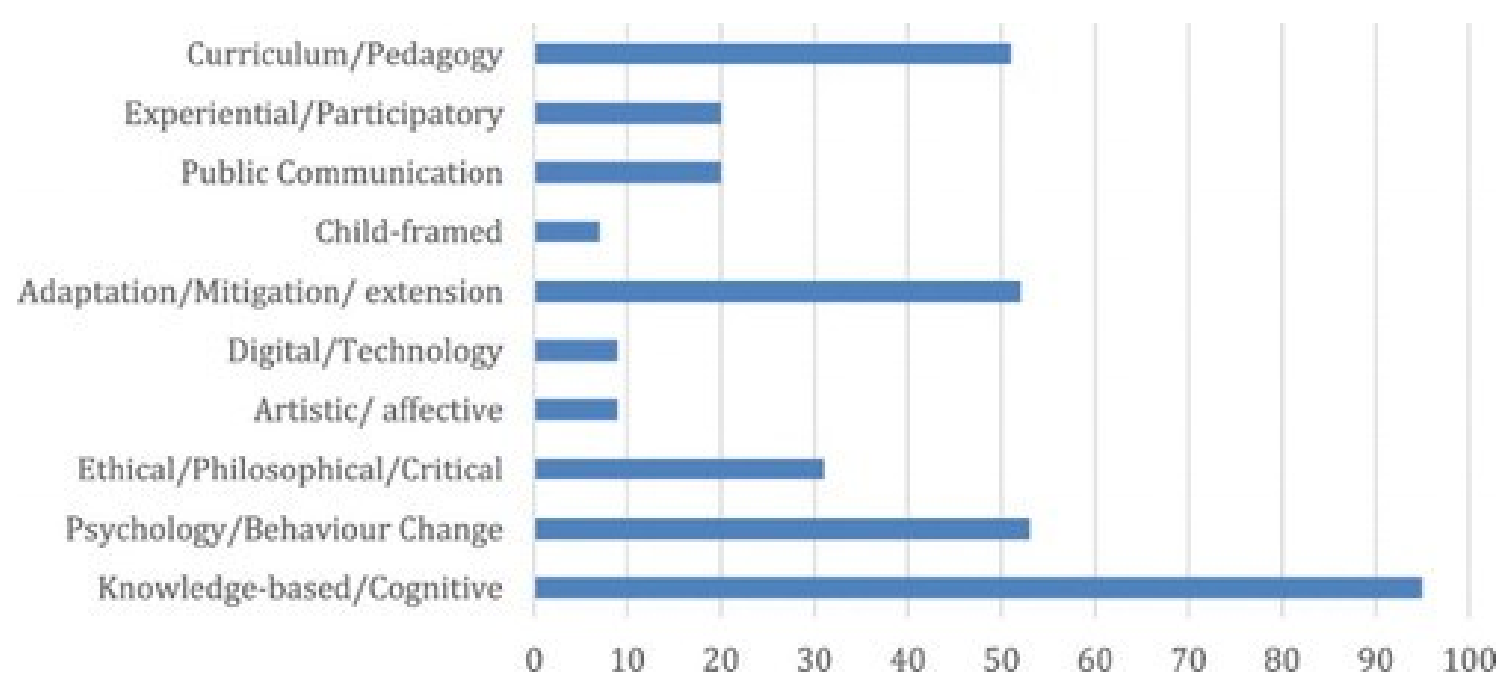

Figure 2: Approaches to climate change education research

Our review also looked at the diversity of educational approaches to climate change education as shown in Figure 2. We found that the science-based approaches that have dominated the literature on climate change education were generally top-down in nature, whether the focus was on scientific knowledge, formal curriculum, behaviour change, or disaster mitigation/adaptation. Yet underneath this entrenched edifice of top-down education and disaster management, a series of innovative, bottom-up approaches have begun to emerge. These include participatory approaches that empower communities of learners to design their own climate change projects and modes of engagement with the issue (Ashley, Kenton \& Milligan 2009; Feirebend \& Eilks, 2011; Figueiredo \& Perkins, 2013). A small number of studies also focused specifically on affective approaches that provoke emotional and somatic responses to climate change issues and concerns through engagement with art, imagery and narrative (Leiserowitz, 2006; Duxbury, 2010). Digital technology has also emerged as a 
modality that has multiple applications for producing innovative and empowering forms of climate change education (Lee et al, 2013; Han et al, 2011; Meymeris et al, 2008). And lastly, a very small contingent of the literature is orientated towards child-framed approaches to climate change education, which draw on the unique perspectives and experiences of children and young people to inform new frameworks and methods for teaching and learning about climate change (Tanner, 2010; Lawler \& Patel, 2012; Makrakis, 2012). The following section offers a brief review of research in this area, providing the overarching context for the childframed methodology developed for the Climate Change and Me project.

\section{Children Researching Children}

For the purposes of this paper, key findings from our literature review included the need for new approaches to climate change education that are orientated towards political, affective, creative and participatory responses to the issue. While climate change education is increasingly identified as essential for all children and young people, their actual voices on environmental issues have often been taken for granted in the broader field of environmental education research. Nearly two decades ago, Payne's (1998) influential article "Children's Conceptions of Nature" considered children's concepts and orientations towards nature and the environment. He argued:

There is a lack of consideration in environmental education theory and research practice about the children who are the subjects of environmental education. There is a need for teachers and curriculum designers to pay much attention to the routines, patterns and rhythms of children's daily lives - their individual and collective ontology requires explanation, or study or what it is for them 'to be in the world'. Learners already have a rich working knowledge of the social and environmental circumstances and living patterns in which they find themselves, including concepts like 'nature' or 'the environment' which are so central to environmental education (p.20).

This question of children and young people's voices and ontological status remains largely unaddressed in environmental education research. As Kellett $(2005$, p. 2) argues, children should be 'acknowledged as experts on their own lives and if adults genuinely want to understand children and childhood, better ways to seek out child perspective and unlock child 
voice must be sought.' In other words, where are children positioned as the actual researchers - as experts on their own lives - in environmental education and its research? More recently a significant trend has emerged in which educational researchers have made significant headway in involving children as legitimate participants and/or co-researchers in environmental education research (Bell, 2008; Morrow, 2008; Skelton, 2008). Indeed Flutter and Ruddock (2004) note that 'there is clear evidence that the political and social climate has begun to warm to the principle of involving children and young people [in research]' (p. 139). Despite such acknowledgement, 'research agendas involving children are still often conceived of and led by adults,' particularly as it concerns environmental education and its research (Cutter-Mackenzie et al, 2013) . As Cutter-Mackenzie et al (2013) further note:

We challenge environmental education researchers to further consider, discuss and critique children's roles in research. We propose that this debate focuses on the potential of children as collaborators in research rather than objects of investigation or discussion. The research methodology "children as active researchers" has received limited attention in environmental education research. Researchers, teachers, politicians, policy makers and curriculum developers demonstrate concern about the sustainability of children's futures and identify children as primary participants in environmental education. Nevertheless, children are not often positioned as researchers who can bring valid and new views or voices to educational practice and policy (p. 456).

While we acknowledge that some research has moved in this direction, we further argue that the discourse around child-framed methodologies needs to extend beyond simply listening to what children have to say, and actually begin to position children as researchers who directly influence the methodology, analysis and outcomes of a given study. This is essentially a question of children's political agency as much as a question of voice, as exemplified by children and young people becoming politically active through social movements such as the 'Australian Youth Climate Coalition' (see http://www.aycc.org.au/). The crossover from such direct environmental activism to the field of research is by and large absent in the traditional genres of environmental education and its research (Cutter-Mackenzie, 2014). Such omissions highlight the importance of the Climate Change $+\mathrm{Me}(\mathrm{CC}+\mathrm{Me})$ project where children and young people were indeed co-researchers as well as authors of their own research. In addition, the showing of their research in the Past Now Future exhibitions enabled 
them to make a direct and tangible socio-political impact within their schools, communities and environments. We now discuss the $\mathrm{CC}+$ Me project, methodology and findings, before returning to the broader issues of climate change education and children's agency in the final section.

\section{Project Design and Methodology}

The Climate Change + Me project is funded by the NSW (New South Wales, Australia) Environmental Trust which is an independent statutory body established by the NSW government to fund a broad range of organisations to undertake projects that enhance the environment of NSW. Working towards the NSW 2021 goals, the CC + Me project aims to strengthen local environments and communities by increasing opportunities for children and young people to be proactive in climate change education. The core audience of the Climate Change and Me program are children and young people aged 9-14 in Northern regional NSW. They were selected because children are often targeted but rarely consulted as legitimate contributors to educational research and curriculum development (Kellett, 2005). The project is thus unique by providing a platform for children and young to engage directly in the climate change debate and indeed their associated education. The project specifically engages children as co-researchers through a creative, ethnographic and actiondriven process. This process has resulted in the development of an online social media platform and network; the Past Now Future community exhibitions in public spaces; an interdisciplinary Climate Change Curriculum; and the Climate Change Challenge, a community event which brings together local schools, climate scientists, environmental artists and writers, and members of the wider community to address the challenges of climate change (see Figure 3). 


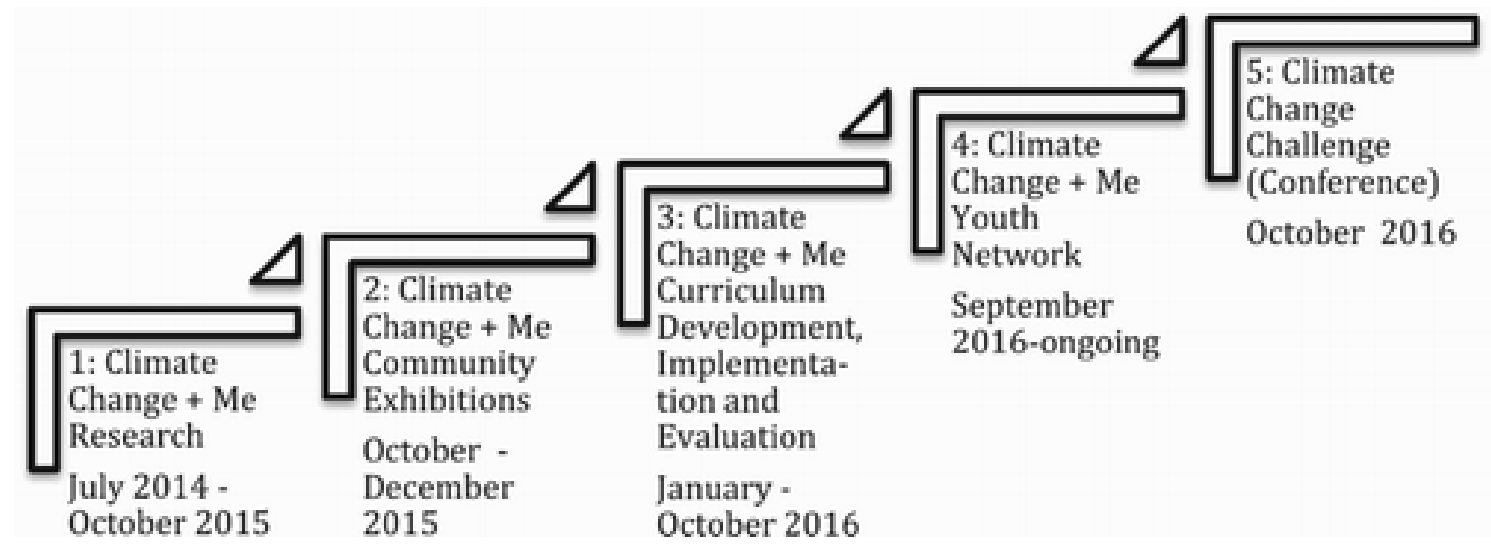

Figure 3: 5 Key Phases of Climate Change + Me Project

Each of these phases is contextualised within the overarching child-framed methodology developed by co-authors Cutter-Mackenzie and Rousell (2014a), while also extending this methodology through the inclusion of methods associated with arts-based and postqualitative research practices. Cutter-Mackenzie has innovated a child-framed approach to environmental education research through her ground-breaking work with children as researchers in major studies around the world (Cutter-Mackenzie, 2014a; Cutter-Mackenzie et al, 2013). Co-author (Rousell, 2015) has a background as a professional fine artist and arts educator, and has also developed a post-qualitative methodology for transdisciplinary participatory research in higher education (Rousell, 2015; Rousell, 2014b). In bringing these two methodological approaches together, the Climate Change and Me project allowed for previous frameworks of child-framed research to be extended into the areas of arts-based research (Eisner, 2004; Barone, 2006) and post-qualitative inquiry (Lather \& St. Pierre, 2013). Crucially, this extension of the methodology was driven by the children and young people themselves who participated as co-researchers in the study. While they were initially trained in ethnographic interview techniques and visual methods, we also supported them in extending their inquiries through creative practices of their own choosing. These extensions of the methodology through the children's poetry, fiction, drawing and dramatic works were then brought back into the workshops to stimulate collective responses from the wider research cohort, thus forming the basis for the final bodies of work assembled for the Past Now Future exhibitions. The analytic and curatorial work undertaken for the exhibitions then laid the groundwork and offered key resources for the development of the Climate Change and Me Curriculum. Through this dynamic and emergent process, we deliberately allowed for the creative practices and theorisations of the children to dynamically impact on the methodology itself as it was unfolding in real time. 
A unique contribution of this research to the development of child-framed methodologies has been the construction of what we have termed the 'co-research playspace', in which children and young people are given the skills, experience and support needed to produce legitimate research outputs to a rigorous standard of conceptualisation and aesthetic quality (CutterMackenzie \& Rousell, 2018; 2014b). In developing our approach to the co-research playspace, we drew on the empirically-grounded theories of environmental psychology to inform the designs of our research training workshops, website and social media platform, curriculum codesign process, and collaborative modes of interaction with the children and young people more broadly. This included the use of D.W. Winnicott's (1989) concepts of transitional space, transitional objects and the 'good enough holding environment' to account for a methodological approach that is orientated towards creativity, experimentation, transition and emergence. Drawing on close observation of children's environmental play, Winnicott argued that learning takes place through creative modes of engagement and experimentation that put internal and external worlds into transformative relation. In the context of this project, the iPad acted as a transitional object which operated both as a mirror (opaque) and a window (transparent) simultaneously (Cutter-Mackenzie \& Rousell, 2018). The device (iPad) opened a window into the child's research world, which was juxtaposed between what some term 'childish or playful' and 'deeply profound'. As Ellsworth $(2005$, p. 30) further explains, such transformations only become possible when children 'dare to move into relation with the outside world of things, other people, environments, and events'. This relational understanding of the learning process means that transitional spaces open up when children are given the tools to experiment with their environments independently from pre-existing authority figures and social structures.

Winnicott's concepts have helped us to account for the ways that children can inquire into the psychological, social and environmental impacts of climate change in ways that are playful, transitional and noncompliant with predetermined expectations or structures. At the same time, we designed our co-research playspace to offer the necessary support infrastructures to enable the children to develop their potential as researchers, artists, writers and theorists. As Ellsworth (2005) argues:

An environment of interrelationship holds the potential to become transitional space when it provides opportunities for us to both act in the world and be acted 
upon by it- while at the same time offering us the flexible stability we need to risk allowing ourselves to be changed by this interaction (p. 32).

Indeed, this notion directly informed our workshop, website and exhibition designs as 'coresearch play spaces' which afforded the flexible stability the children needed to takes risks in the development of their own research practices. In this sense, the children were supported in developing their own approaches to the project that often exceeded or broke with our own expectations, and these emergent, child-driven practices were then allowed to impact on the overall methodological trajectory of the project itself. This was particularly evident in the curatorial analysis of the research data, as undertaken in collaboration with children and young people in the preparation of the Past Now Future exhibition. The following section offers a brief overview of this process, with a series of examples from each of the three collaborative works that were created for the exhibition.

\section{Past Now Future}

The Past Now Future exhibition took place over a three-month period in 2015 , and was presented at eight public libraries in communities across Northern NSW (see Figure 5). The exhibition was viewed by over 8,000 members of the public, and was also documented by local newspapers and on $A B C$ National Radio through interviews with several of the young researchers. The exhibitions presented the culmination of a year's worth of fieldwork by the 135 participating co-researchers. The co-researchers were actively involved with all aspects of the exhibition as a curatorial and analytic process, including the titling, selection of works, locations, and artist/researcher statements. The following sub-sections offer vignettes based on each of the three major collaborative works developed for the Past Now Future exhibitions. The first work, Pieces of the Earth, consists of 135 digital images transferred into encaustic wax medium on plywood tiles. The second work is called Voices from the Anthropocene, and consists of three hyperlinked video artworks exploring the attitudes, awareness and actions of young people in response to climate change. The third work takes the form of an edited exhibition book featuring the essays, poems, photovoice montages, drawings and fictional narratives created by the co-researchers. Each of the vignettes below thus aims to maintain the integrity of the three works as resolved, collaborative works of art, media, creative writing and theorization produced by and for children and young people. Comments from the student researchers are also used to further contextualize these works not only as research outputs, but also as dynamic pedagogical processes that revealed valuable insights into the crucial role of creativity in child-framed research. 

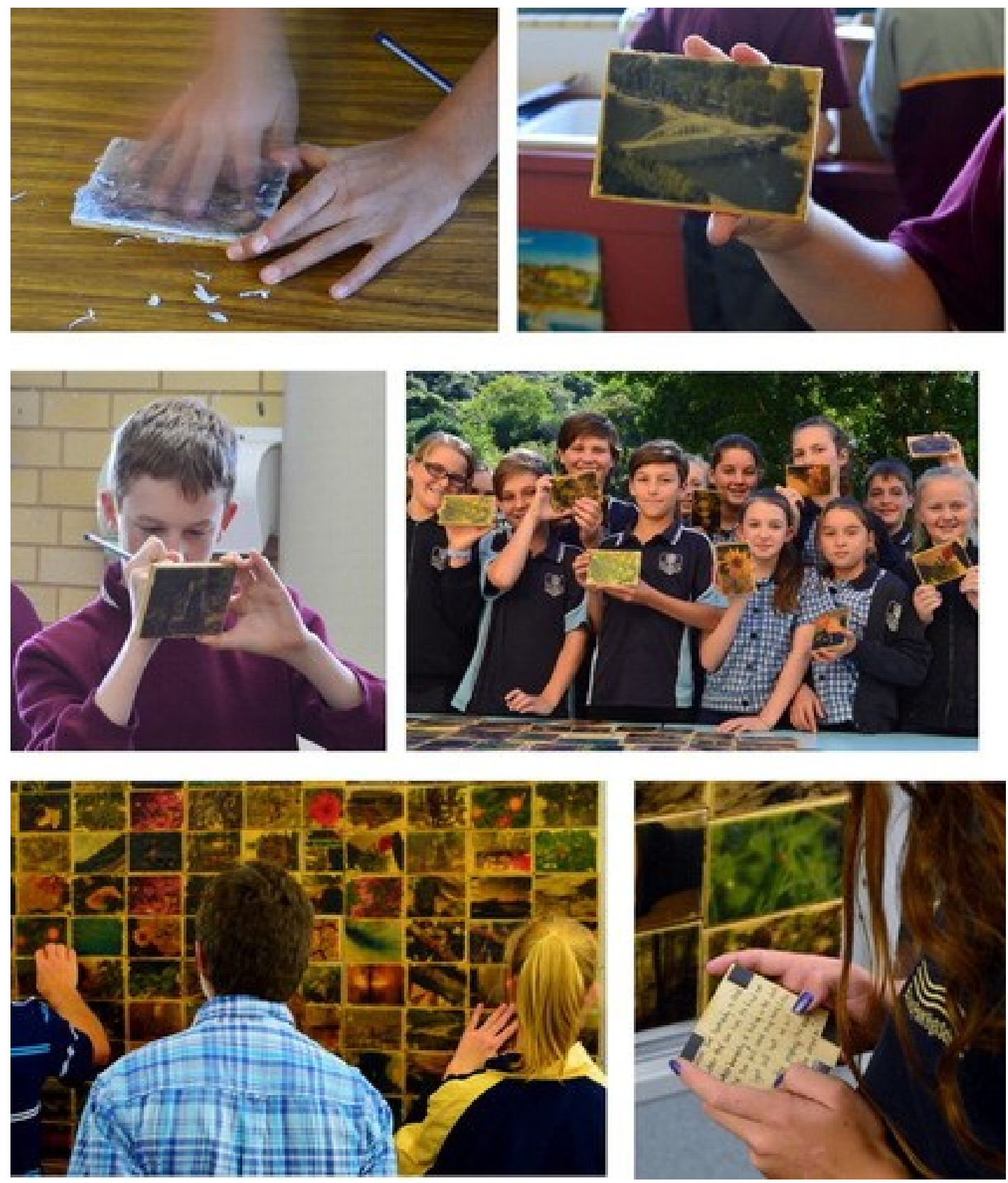

Figure 4. Pieces of the Earth. Learning about climate through different artistic media was a great experience and learning time to have. Creative ideas help young people understand and absorb issues like climate change in a much more enjoyable, stimulating and interactive environment. Exhibitions can also do lots to help attract attention from communities so they become more interested in learning about climate change from different points of view. Pay attention; look carefully. What we are about to show you is not from around the world, but from here in our hearts and minds. Here in our lives, here in our communities, and here in our schools. 

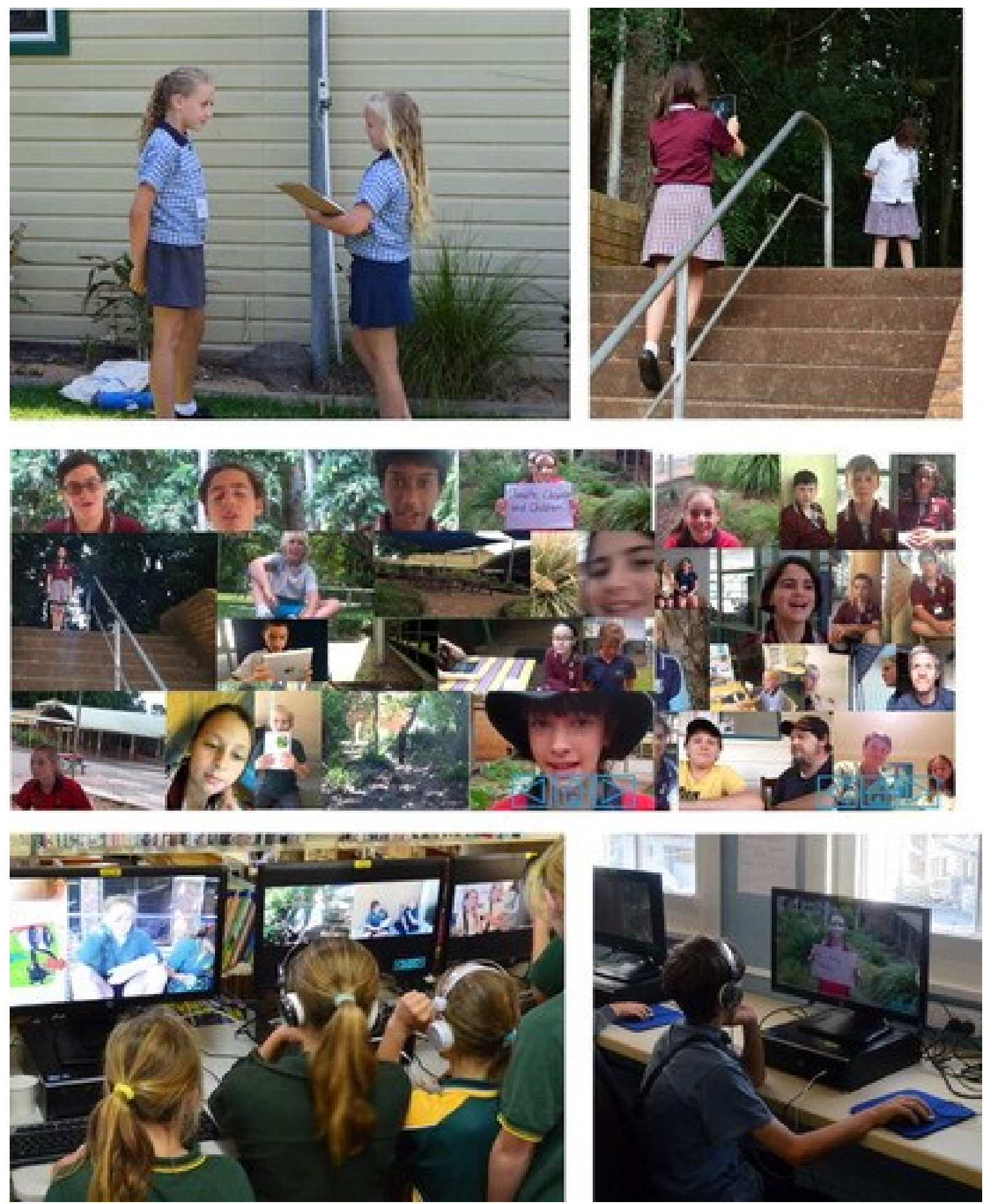

Figure 5. Voices from the Anthropocene. When my friends and I began to research climate change, interview our friends and put videos together as a result, it was quite eye-opening to realise what we could do to save our dying world. Past Now Future is about us taking a stand and having a voice about climate change. It's about us researching the real life experiences and opinions of children and young people. It's about researching ourselves too, as kids who care about climate change and want to do something. Our goal with this exhibition is to show you what climate change looks like, what it sounds like, what it feels like, and what it might become in the future. 

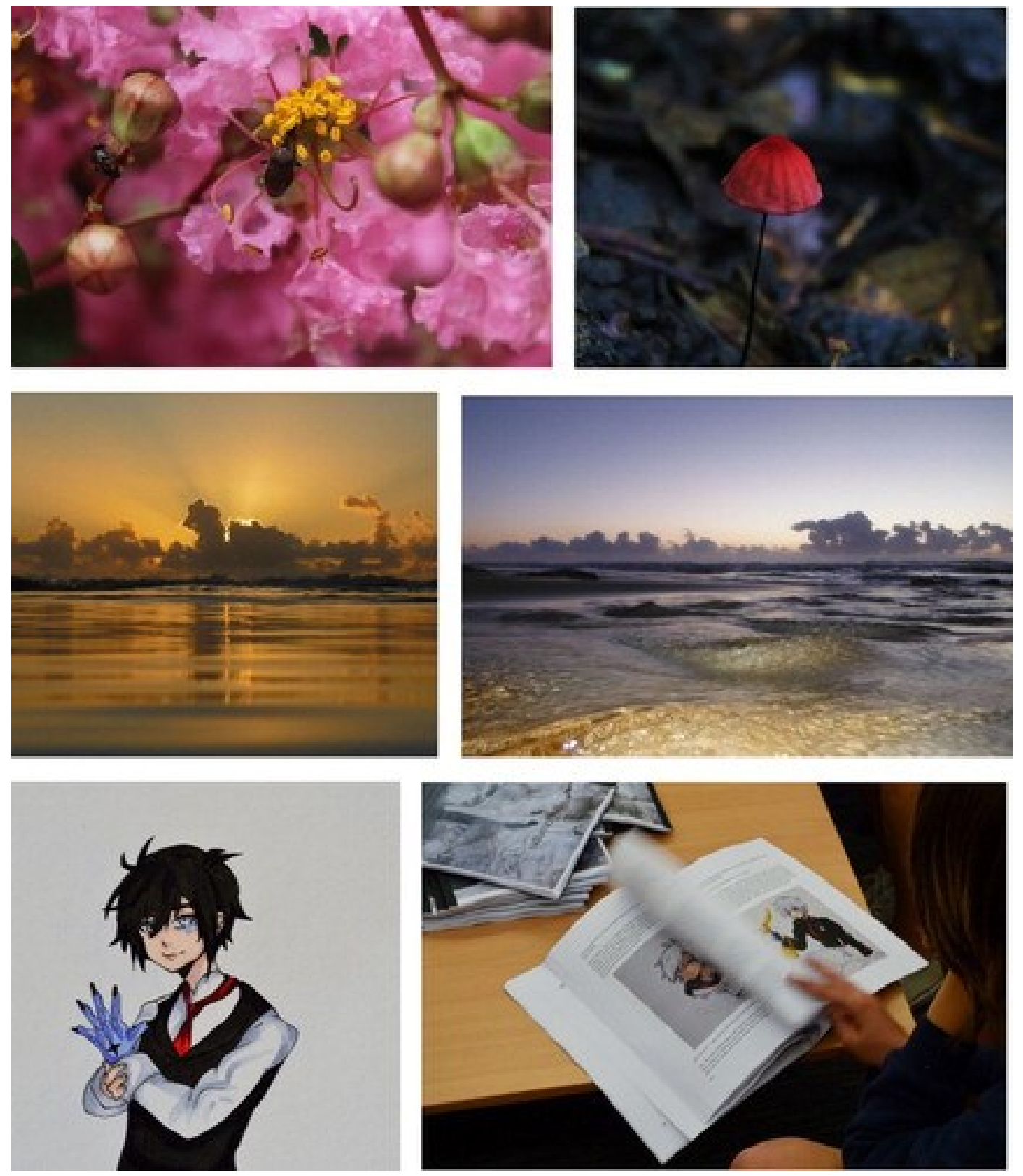

Figure 6. The Changes. The difference must begin with us. We must make drastic changes to how we think and make choices about our everyday activities and focuses. We were not placed on this Earth to make an acquisitive and ideal life that supports the human race only; we were placed on this planet to foresee a life for all things, whether they are living, or non-living, plant or animal. Not to destroy the climate by means of our own self-centred needs. It is dark on the HORIZON ... but through this project it is becoming clearer. Clearer of the way out of the dark, to the age of natural information. The heat, the cold; they cannot become extreme ... or we will die. Aoi was so interested in this topic and he wanted people to become more aware, but how could he make a difference? He was only a child in the eyes of the public, not likely to be taken seriously. What could he do to help stop climate change? 


\section{Discussion: Education for What?}

These three vignettes of the children and young people's research offer a powerful series of challenges, provocations and opportunities for researchers, educators and policy makers. They provoke us to re-think curriculum well beyond the question of climate change content, and to consider creative and visionary alternatives that deviate from anthropocentric and scientistic modes of education, research and thought. Existing climate change education research has tended to focus on children and young people's conceptual knowledge of climate change, often describing it as limited, erroneous and highly influenced by mass media (see Lombardi, 2010). This project did not reveal limited or erroneous knowledge, but rather insightful, creative and politically active young people capable of producing finely tuned research outputs.

We now return to the argument initiated at the start of the paper regarding children's voice and political agency in climate change discourse and education. Based on our experiences working on this project, we argue that listening to what children say is not enough in the context of climate change education or child-framed methodologies more broadly. Rather, we propose that such research should position children as legitimate practitioners capable of producing finely tuned research outputs with the potential for significant social and political impact. Crucial to this argument is the positioning of children as active researchers, as artists, as writers, as social scientists and even as philosophers. If, as the Anthropocene thesis suggests, social and environmental change is far outpacing current ways of knowing, shouldn't we be working directly with children and young people to create new knowledge practices that are responsive to such change? The implication of such a positioning is that children know things that we, as adults, do not know. These precious knowings can only come to light if we radically rethink the political positioning of children not only in research, but in the home, the school, and society more broadly.

In consideration of the naming and framing fragmentations of environmental education and its iterations (including education for sustainable development and education for sustainability), the children and young people's research cuts through the semantics to speak more widely than the partiality of 'sustainability' or 'sustainable development'. In fact, none of our co-researchers mentioned the word sustainability in the workshops, interviews, website, poems or other creative works generated over the course of the project. While the authors did discuss sustainability at the research workshops and asked the students why they 
did not use the concept, the co-researchers tended to make comments such as 'because it's meaningless'. Rather than sustainability, they gravitated towards vitalist concepts of coexistence that de-centred human agency and superiority and (re)connected with more than human elements of the earth's biosphere and climatic systems. To us, this indicates that the concept of sustainability bears little to no traction with children and young people who recognise Earth's climate change (historically and in the Anthropocene) as a catastrophic social and environmental event. The latter point is echoed by Jickling (1991, pp. 154-155), who argued that students should participate 'as intelligent individuals in the constant reexamination and re-casting of society', and critically evaluate the terms and conditions of their own educations. However, we revise Jickling's emphasis on the discerning intelligence of the individual to account for the ways that agency, voice and participation are located within political ecologies that always exceed the human (Bennett, 2010). This eco-ontological shift is born out in the findings of our co-researchers above, in which they reveal their capacity to conduct research outside of the cognitive, human-centred schematics induced by traditional schooling.

\section{Conclusion}

In conclusion, the question of 'education for what?' which has troubled environmental education research for decades remains deliberately unanswered. While Jickling's (1991) seminal article is now some 20 years old, his fundamental argument still applies as it concerns the problematic nature of education for sustainable development, education for sustainability and environmental education initiatives which fail to critically engage their own publics. While these fields developed in response to environmentalist, conservationist and even economic rationalist concerns, climate change education emerges at a time when such humanist ideologies of unmitigated progress and techno-centric management are necessarily being called into question. Thus 'education for' becomes a moot point, and if climate change education is to progress we must move beyond the discipline boundaries of environmental education, education for sustainable development and education for sustainability (and other sustainability-education modes). We argue that climate change education does not simply slip into one of these disciplines or sub-disciplines, but presents an emerging field of practice and research that is fundamentally responsive and accountable to the rapidly changing environmental conditions of everyday life.

These findings from the Climate Change and Me project suggests that climate change 
education can open up an entirely new field of educational experience and inquiry that is profoundly different from existing modes of environmental or sustainability education. For our co-researchers, creativity and the arts are crucial to this new formulation of educational experience and inquiry. For ourselves as educational researchers, we are both invigorated and hopeful that children and young people might be the ones to determine the shape of this new field in the making.

\section{References}

Anderson, A. 2012. "Climate Change Education for Mitigation and Adaptation." Journal of Education for Sustainable Development 6 (2): 191-206. doi: 10.1177/0973408212475199

Ashley, H., N. Kenton, and A. Milligan, eds. 2009. Community-based Adaptation to Climate Change. London: International Institute for Environment and Development.

Barone, T. 2006. "Arts-Based Educational Research Then, now and Later." Studies in Art Education 48 (1): 4-8. doi: 10.1080/00393541.2006.11650495

Barone, T., and E. Eisner. 2012. Arts Based Research. Thousand Oaks, CA: Sage Publications, Inc.

Barratt Hacking, E., A. Cutter-Mackenzie, and R. Barrratt. 2013. “Children as Active Researchers: The Potential of Environmental Education Research Involving Children." In The Handbook of Research on Environmental Education, edited by R. Stevenson, A. Wals, M. Brody, and J. Dillon, 438-458. Washington: American Educational Research Association/Routledge.

Bell, N. 2008. "Ethics in Child Research: Rights, Reason and Responsibilities." Children's Geographies 6 (1): 7-20. doi: 10.1080/14733280701791827

[Taylor \& Francis Online], [Web of Science $\left.{ }^{\circledR}\right]$

Bennett, J. 2010. Vibrant Matter: A Political Ecology of Things. Durham, NC: Duke University Press.

Blum, N., J. Nazir, S. Breiting, K. C. Goh, and E. Pedretti. 2013. "Balancing the Tensions and Meeting the Conceptual Challenges of Education for Sustainable Development and Climate Change." Environmental Education Research 19 (2): 206-217. doi: 10.1080/13504622.2013.780588

Brownlee, M., R. B. Powell, and H. C. Jeffery. 2013. "A Review of the Foundational Processes that Influence Beliefs in Climate Change: Opportunities for Environmental Education Research." Environmental Education Research 19 (1): 1-20. doi: 10.1080/13504622.2012.683389 
Choi, S., D. Niyogi, D. P. Shepardson, and U. Charusombat. 2010. “Do Earth and Environmental Science Textbooks Promote Middle and High School Students' Conceptual Development about Climate Change? Textbooks' Consideration of Students' Misconceptions." Bulletin of the American Meteorological Society [0003-0007]91 (7): 889-898. doi: 10.1175/2009BAMS2625.1

Crate, S. A., and M. Nuttall, eds. 2009. Anthropology and Climate Change: From Encounters to Actions. Walnut Creek, CA: Left Coast Press.

Cutter-Mackenzie, A. 2014. "Where are Children and Young People in Environmental Education Research? Special Issue (30 Year Anniversary Issue) Guest Edited by Annette Gough, Noel Gough, Hilary Whitehouse and Amy Cutter-Mackenzie." Australian Journal of Environmental Education 30 (1): 103105. doi: 10.1017/aee.2014.32

Cutter-Mackenzie, A., and D. Rousell. 2018. "The Mesh of Playing, Theorising and Researching in the Reality of Climate Change: Children's Chldhoodnature Research Playspaces." In Research Handbook on ChildhoodNature: Assemblages of Childhood and Nature Research, edited by A. Cutter-Mackenzie, K. Malone, and E. Barratt Hacking. New York, USA: Springer Nature.

Dijkstra, E. M., and M. J. Goedhart. 2012. "Development and Validation of the ACSI: Measuring Students' Science Attitudes, Pro-Environmental Behaviour, Climate Change Attitudes and Knowledge." Environmental Education Research 18 (6): 733-749. doi: 10.1080/13504622.2012.662213

Duxbury, L. 2010. “A Change in the Climate: New Interpretations and Perceptions of Climate Change Through Artistic Interventions and Representations." Weather, Climate, and Society 2 (4): 294-299. doi: 10.1175/2010WCAS1053.1

Ellsworth, E. 2005. Places of Learning: Media, Architecture, Pedagogy. Abingdon, UK: Routledge.

Feierabend, T., and I. Eilks. 2011. "Innovating Science Teaching by Participatory Action Researchreflections from an Interdisciplinary Project of Curriculum Innovation on Teaching About Climate Change." CEPS Journal 1 (1): 93-112.

Figueiredo, P., and P. E. Perkins. 2013. "Women and Water Management in Times of Climate Change: Participatory and Inclusive Processes." Journal of Cleaner Production 60: 188-194. doi: 10.1016/j.jclepro.2012.02.025

Flutter, J., and J. Rudduck. 2004. Consulting Pupils: What's in it for Schools? London: Routledge Falmer. 
Fortner, R. W. 2001. “Climate Change in Schools: Where Does it Fit and How Ready are we?” Canadian Journal of Environmental Education 6: 18-32.

Garnaut, R. 2011. THE GARNAUT REVIEW 2011: Australia in the Global Response to Climate Change. New York City: Cambridge University Press.

Hallar, A. G., I. B. McCubbin, and J. M. Wright. 2011. "CHANGE: A Place-Based Curriculum for Understanding Climate Change at Storm Peak Laboratory, Colorado." Bulletin of the American Meteorological Society 92 (7): 909-918. doi: 10.1175/2011BAMS3026.1

Hart, P., and K. Nolan. 1999. "A Critical Analysis of Research in Environmental Education." Studies in Science Education 34 (1): 1-69. doi: 10.1080/03057269908560148

Hill, M. 2006. “Children's Voices on Ways of Having a Voice: Children's and Young People's Perspectives on Methods Used in Research and Consultation." Childhood (copenhagen, Denmark) 13 (1): 69-89.

IPCC (Intergovernmental Panel on Climate Change). 2001. Climate Change 2001: Synthesis Report. Contribution of Working Groups I, II and III to the Third Assessment Report of the Intergovernmental Panel on Climate Change. Geneva, Switzerland: IPCC.

IPCC (Intergovernmental Panel on Climate Change). 2007. Climate Change 2007: Synthesis Report. Contribution of Working Groups I, II and III to the Fifth Assessment Report of the Intergovernmental Panel on Climate Change. Geneva, Switzerland: IPCC.

IPCC (Intergovernmental Panel on Climate Change). 2014. Climate Change 2014: Synthesis Report. Contribution of Working Groups I, II and III to the Fifth Assessment Report of the Intergovernmental Panel on Climate Change. Geneva, Switzerland: IPCC.

Jickling, B. 1991. "Environmental Education, Problem Solving and Some Humility Please." Trumpeter 3 (3): 153-155.

Kagawa, F., and D. Selby, eds. 2009. Education and Climate Change Living and Learning in Interesting Times. London, UK: Routledge.

Kellett, M. 2005. How to Develop Children as Researchers: A Step-by-Step Guide to Teaching the Research Process. London: Sage Publications.

Læssøe, J., K. Schnac, S. Breiting, and S. Rolls. 2009. “Climate Change and Sustainable Development: 
The Response from Education." International Alliance of Leading Educational Institutes.

Lather, P., and E. A. St. Pierre. 2013. "Post-qualitative Research." International Journal of Qualitative Studies in Education 26 (6): 629-633. doi: 10.1080/09518398.2013.788752

Lawler, J., and M. Patel. 2012. “Exploring Children's Vulnerability to Climate Change and Their Role in Advancing Climate Change Adaptation in East Asia and the Pacific." Environmental Development 3: 123-136. doi: 10.1016/j.envdev.2012.04.001

Lee, J. J., P. Ceyhan, W. Jordan-Cooley, and W. Sung. 2013. "Greenify: A Real-world Action Game for Climate Change Education." Simulation and Gaming 44 (2-3): 349-365. doi: $10.1177 / 1046878112470539$

Leiserowitz, A. 2006. "Climate Change Risk Perception and Policy Preferences: The Role of Affect, Imagery, and Values." Climatic Change 77 (1-2): 45-72. doi: 10.1007/s10584-006-9059-9

Lombardi, D., and G. M. Sinatra. 2010. “College Students' Perceptions About the Plausibility of Human Induced Climate Change." Research in Science Education 42 (2): 201-217. doi: 10.1007/s11165-0109196-z

Lowe, T., K. Brown, S. Dessai, M. de Franca Doria, K. Haynes, and K. Vincent. 2006. "Does Tomorrow Ever Come? Disaster Narrative and Public Perceptions of Climate Change." Public Understandings of Science 15: 435-457. doi: 10.1177/0963662506063796

Malone, K. 2004. “Holding Environments: Creating Spaces to Support Children's Environmental Learning in the 21st Century." Australian Journal of Environmental Education 20 (2): 53-66. doi: $10.1017 /$ S0814062600002202

Malone, K., S. Truong, and T. Gray. 2016. Reimagining Sustainability in Precarious Times. Singapore: Springer.

Meymeris, K., S. Henderson, P. Alaback, and K. Havens. 2008. Project BudBurst: Citizen science for all seasons. Paper presented at AGU Fall Meeting Abstracts.

Morrow, V. 2008. "Ethical Dilemmas in Research with Children and Young People about their Social Environments." Children's Geographies 6 (1): 49-61. doi: 10.1080/14733280701791918

Payne, P. 1998. “Childrens' Conceptions of Nature." Australian Journal of Environmental Education 14: 
Rousell, D. 2015. "The Cartographic Network: Re-Imagining University Learning Environments Through the Methodology of Immersive Cartography." Multidisciplinary Research in the Arts 5 (1): 1-33.

Rousell, D., and A. Cutter-Mackenzie. 2015. The Changes - Art, Writing and Research by Student Researchers in the Climate Change and Me Project. Gold Coast, Australia: NSW Environmental Trust.

Rousell, D., A. Cutter-Mackenzie, and J. Foster. 2017. “Children of an Earth to Come: Speculative Fiction, Geophilosophy and Climate Change Education Research." Special Issue for Educational Studies 53 (6): 654-669. doi: 10.1080/00131946.2017.1369086

Selby, D., and F. Kagawa. 2010. "Runaway Climate Change as Challenge to the 'Closing Circle' of Education for Sustainable Development." Journal of Education for Sustainable Development 4 (1): $37-$ 50. doi: $10.1177 / 097340820900400111$

Sharma, A. 2012. "Global Climate Change: What Has Science Education got to do with it?" Science \& Education 21 (1): 33-53. doi: 10.1007/s11191-011-9372-1

Shepardson, D. P., D. Niyogi, S. Choi, and U. Charusombat. 2009. “Seventh Grade Students' Conceptions of Global Warming and Climate Change." Environmental Education Research 15 (5): 549-570. doi: $10.1080 / 13504620903114592$

Skelton, T. 2008. "Research with Children and Young People: Exploring the Tensions Between Ethics, Competence and Participation." Children's Geographies 6 (1): 21-36. doi: $10.1080 / 14733280701791876$

Stokols, D., S. Misra, M. G. Runnerstrom, and J. A. Hipp. 2009. "Psychology in an Age of Ecological Crisis: From Personal Angst to Collective Action." American Psychologist 64 (3): 181-193. doi: $10.1037 / \mathrm{a} 0014717$

Tanner, T. 2010. "Shifting the Narrative: Child-led Responses to Climate Change and Disasters in EI Salvador and the Philippines." Children and Society 24: 339-351. doi: 10.1111/j.10990860.2010.00316.x

Tucci, J., J. Mitchell, and C. Goddard. 2007. Children's Fears, Hopes and Heroes: Modern Childhood in Australia. Melbourne: Australian Childhood Foundation. 
Turpin, E., and H. Davis. 2015. “Art \& Death: Lives Between the Fifth Assessment \& the Sixth Extinction.” In Art in the Anthropocene: Encounters among Aesthetics, Politics, Environments and Epistemologies, edited by H. Davis, and E. Turpin, 3-30. London, UK: Open Humanities Press.

Winnicott, D. W. 1989. Playing and Reality. New York: Routledge.

Wise, S. B. 2010. "Climate Change in the Classroom: Patterns, Motivations, and Barriers to Instruction Among Colorado Science Teachers." Journal of Geoscience Education 58 (5): 297-309. doi: 10.5408/1.3559695 